\title{
Adrenosympathetic overactivity under conditions of work stress
}

\author{
MARIO TIMIO AND SIMONETTA GENTILI \\ From the Institute of Patologia Speciale Medica and Metodologia Clinica, University of Perugia, Italy
}

\begin{abstract}
Timio, M. and Gentili, S. (1976). British Journal of Preventive and Social Medicine, 30, 262-265. Adrenosympathetic overactivity under conditions of work stress. Serial measurements of urinary adrenaline, noradrenaline, and 11-hydroxycorticosteroid excretion were performed on 32 healthy men under two conditions of work stress; piecework and work on assembly line. A statistically significant increase in adrenaline, noradrenaline, and 11hydroxycorticosteroids was observed for piecework and assembly line workers compared with salaried and 'ordinary' workers. The results support the assumption that psychosocial factors of an everyday type have significant effects on the sympathoadrenomedullary and adrenocortical function.
\end{abstract}

It is well known that various stresses can lead to sympathetic overactivity. The role of the sympathetic nervous system in certain aspects of the 'stress construct' has been evaluated in a number of studies by analysing urinary adrenaline and noradrenaline excretion, as increased levels of urinary catecholamines are observed under stress-such as, physical overactivity (Raven, Conners, and Evonuk, 1970), excessive mental effort (Levi, 1972a), or high levels of industrial noise and vibration (Anitesco, 1972). However, as few studies have been concerned with the physiological and psychological effects of work stress, the current study was conducted to ascertain whether some work systems-such as, piecework and assembly line-modify sympathoadrenal and adrenocortical activity.

\section{METHODS}

Thirty-two male workers aged between 23 and 39 years (average 29) took part in this study. They were all apparently in good health and had normal 12-lead electrocardiograms.

After they had been told about the aim and procedure of the study, all the workers agreed voluntarily to take part. They were divided into two groups according to their job:

Group I: 16 confectioners (pieceworkers)

Group II: 16 metallurgists (assembly line workers)

They were all well trained. In order to avoid the possibility that the response of the workers might have been conditioned in advance because we had told them the aim of the research, a crossover design was used dividing each group into two subgroups $\mathrm{g}^{\mathbb{D}}$ eight workers. Each subgroup performed the activi $\vec{\theta}$ for three periods and each lasted four consecutize working days (seven hours daily) in accordance wit the following schedules:

Schedule A: the first subgroup of confectioners started under piecework conditions, continued on daily salary, then performed again piecework $\stackrel{\mathbb{\Omega}}{\stackrel{\perp}{\varrho}}$ (piecework/salary/piecework);

Schedule B: the second subgroup of confectioners after the first period on daily salary, continued on piecework conditions, and returned to salariedo work (salary/piecework/salary);

Schedule C: the first subgroup of metallurgists worked on the assembly line, during the second $:$ period performed 'ordinary' work (outside the 3 . assembly line), then returned to the assembly line $\delta$ (assembly line/ordinary work/assembly line);

Schedule D: the second subgroup of metallurgists $\mathrm{O}$ began with the 'ordinary' work, continued on the assembly line, then performed again 'ordinary' work (ordinary work/assembly line/ordinary work).

To minimize errors we adopted standard pro- $\tilde{O}$ cedures which, although not infallible, should have made results more reliable. During the periods of observation their food was free of any substancee that might have influenced urinary catecholamines $\widetilde{\Phi}$ and 11-hydroxycorticosteroid excretion; all drinks? containing ethanol or caffeine were prohibited. No 
subject was taking psychotrophic substances, oral sympathomimetics and sympatholytics, tetracyclines, inhaled vasoconstrictor substances for nasal stuffiness, or corticosteroids. Each worker was instructed not to smoke from the time he awoke to the end of his working day. Working environmental temperature was constant at optimal levels $\left(17^{\circ}-20^{\circ} \mathrm{C}\right)$.

Each subject started work at 7.00 a.m. after he had slept and had a standard breakfast. Each emptied his bladder some 10 minutes before he started work. Urine specimens were then collected in bottles during the seven-hour period and stored at $4^{\circ} \mathrm{C}$. Samples were analysed blind within the following two to three days for adrenaline and noradrenaline, using the method of Crout (1961) modified by Valori et al. (1970), and for corticosteroids (Mattingly, 1962; Mattingly et al., 1964). The results were evaluated statistically. The $t$ values were obtained by paired comparison of the data.

\section{RESULTS}

\section{Group I}

The mean daily urinary adrenaline and noradrenaline excretion in the confectioners increased throughout the four days of piecework, during both the first and second schedule (A and B). During salaried days the urinary levels of catecholamines were normal (Table I). The increase, highly statistically significant $(P<0.01)$, was steady throughout each period of piecework. During the seven-hour period urinary 11-hydroxycorticosteroid excretion increased during piecework in both subgroups, compared with salaried workers (Table I). The difference was significant at a level of $\mathbf{P}<0.01$.

\section{Group II}

During each period of assembly line work performed according to schedules $\mathrm{C}$ and $\mathrm{D}$, the mean seven-hour level of urinary adrenaline and noradrenaline excretion rose significantly $(P<0.01)$ in all metallurgists, compared with values obtained during 'ordinary' work (Table II). Under assembly line conditions the values of mean 11-hydroxycorticosteroid excretion were higher than those found during 'ordinary' work (Table II). The change was statistically significant $(P<0.01)$.

\section{Discussion}

Payment-by-results and assembly line are common working systems. Although there is no doubt that such systems influence productivity, little is

TABLE I

MEAN AND STANDARD ERROR (SEM) FOR URINARY EXCRETION OF ADRENALINE, NORADRENALINE, AND 11-HYDROXYCORTICOSTEROIDS FOR EACH PERIOD DURING PIECEWORK AND DAILY SALARY WORK IN SCHEDULES A AND B

\begin{tabular}{|c|c|c|c|c|c|c|c|c|}
\hline \multirow{2}{*}{$\begin{array}{l}\text { Day } \\
\text { No. }\end{array}$} & \multirow[b]{2}{*}{ Schedule } & \multirow[b]{2}{*}{ Work } & \multicolumn{2}{|c|}{$\begin{array}{c}\text { Adrenaline } \\
\left(\mu_{\mathrm{g} / 7} / 7 \text { hours }\right)\end{array}$} & \multicolumn{2}{|c|}{$\begin{array}{l}\text { Noradrenaline } \\
\text { ( } \mu \mathrm{g} / 7 \text { hours })\end{array}$} & \multicolumn{2}{|c|}{$\begin{array}{l}\text { 11-hydroxycorticosteroids } \\
\text { ( } \mu \mathrm{g} / 7 \text { hours) }\end{array}$} \\
\hline & & & Mean & SEM & Mean & SEM & Mean & SEM \\
\hline 1 & $\mathbf{A}$ & $\begin{array}{l}\text { Piecework } \\
\text { Salary } \\
\text { Piecework }\end{array}$ & $\begin{array}{l}5 \cdot 11 \\
1 \cdot 43 \\
5 \cdot 39\end{array}$ & $\begin{array}{l}0.98 \\
0.29 \\
1.05\end{array}$ & $\begin{array}{l}18 \cdot 31 \\
10 \cdot 43 \\
19 \cdot 01\end{array}$ & $\begin{array}{l}1 \cdot 93 \\
1 \cdot 04 \\
1 \cdot 86\end{array}$ & $\begin{array}{r}171 \cdot 34 \\
86 \cdot 48 \\
168 \cdot 28\end{array}$ & $\begin{array}{r}11 \cdot 43 \\
7 \cdot 33 \\
10 \cdot 96\end{array}$ \\
\hline \multirow{3}{*}{2} & B & $\begin{array}{l}\text { Salary } \\
\text { Piecework } \\
\text { Salary }\end{array}$ & $\begin{array}{l}1 \cdot 50 \\
6 \cdot 01 \\
1 \cdot 63\end{array}$ & $\begin{array}{l}0 \cdot 33 \\
1 \cdot 03 \\
0 \cdot 33\end{array}$ & $\begin{array}{r}10 \cdot 86 \\
19 \cdot 39 \\
9 \cdot 91\end{array}$ & $\begin{array}{l}1.01 \\
2.04 \\
0.98\end{array}$ & $\begin{array}{r}77 \cdot 38 \\
159 \cdot 33 \\
82 \cdot 78\end{array}$ & $\begin{array}{r}8 \cdot 01 \\
12 \cdot 71 \\
7 \cdot 75\end{array}$ \\
\hline & $\mathbf{A}$ & $\begin{array}{l}\text { Piecework } \\
\text { Salary } \\
\text { Piecework }\end{array}$ & $\begin{array}{l}5 \cdot 93 \\
1 \cdot 37 \\
5 \cdot 88\end{array}$ & $\begin{array}{l}1 \cdot 12 \\
0 \cdot 33 \\
0.96\end{array}$ & $\begin{array}{r}17 \cdot 75 \\
8 \cdot 85 \\
19 \cdot 75\end{array}$ & $\begin{array}{l}1.39 \\
0.96 \\
1.95\end{array}$ & $\begin{array}{r}194 \cdot 28 \\
72 \cdot 22 \\
178 \cdot 14\end{array}$ & $\begin{array}{r}10 \cdot 40 \\
6 \cdot 14 \\
9 \cdot 39\end{array}$ \\
\hline & $\mathbf{B}$ & $\begin{array}{l}\text { Salary } \\
\text { Piecework } \\
\text { Salary }\end{array}$ & $\begin{array}{l}1 \cdot 96 \\
6 \cdot 04 \\
1 \cdot 77\end{array}$ & $\begin{array}{l}0 \cdot 52 \\
0 \cdot 99 \\
0 \cdot 39\end{array}$ & $\begin{array}{r}9 \cdot 34 \\
18 \cdot 75 \\
8 \cdot 36\end{array}$ & $\begin{array}{l}1 \cdot 17 \\
2 \cdot 01 \\
2 \cdot 13\end{array}$ & $\begin{array}{r}69 \cdot 23 \\
185 \cdot 68 \\
75 \cdot 16\end{array}$ & $\begin{array}{r}7 \cdot 33 \\
10 \cdot 81 \\
9 \cdot 19\end{array}$ \\
\hline \multirow[t]{2}{*}{3} & $\mathbf{A}$ & $\begin{array}{l}\text { Piecework } \\
\text { Salary } \\
\text { Piecework }\end{array}$ & $\begin{array}{l}6 \cdot 01 \\
2 \cdot 09 \\
5 \cdot 77\end{array}$ & $\begin{array}{l}1 \cdot 09 \\
0 \cdot 39 \\
0.86\end{array}$ & $\begin{array}{r}19 \cdot 01 \\
7 \cdot 14 \\
18 \cdot 33\end{array}$ & $\begin{array}{l}2 \cdot 13 \\
1 \cdot 19 \\
3 \cdot 03\end{array}$ & $\begin{array}{r}188 \cdot 16 \\
66 \cdot 93 \\
162 \cdot 98\end{array}$ & $\begin{array}{l}9 \cdot 71 \\
4 \cdot 86 \\
8 \cdot 69\end{array}$ \\
\hline & $\mathbf{B}$ & $\begin{array}{l}\text { Salary } \\
\text { Piecework } \\
\text { Salary }\end{array}$ & $\begin{array}{l}1 \cdot 73 \\
5 \cdot 88 \\
1 \cdot 96\end{array}$ & $\begin{array}{l}0.44 \\
0.91 \\
0.36\end{array}$ & $\begin{array}{r}8 \cdot 11 \\
20 \cdot 04 \\
9 \cdot 31\end{array}$ & $\begin{array}{l}1 \cdot 63 \\
2 \cdot 24 \\
1 \cdot 35\end{array}$ & $\begin{array}{r}72 \cdot 14 \\
190 \cdot 04 \\
69 \cdot 68\end{array}$ & $\begin{array}{r}5 \cdot 63 \\
12 \cdot 19 \\
6 \cdot 01\end{array}$ \\
\hline \multirow[t]{2}{*}{4} & $\mathbf{A}$ & $\begin{array}{l}\text { Piecework } \\
\text { Salary } \\
\text { Piecework }\end{array}$ & $\begin{array}{l}4 \cdot 09 \\
1 \cdot 93 \\
5 \cdot 32\end{array}$ & $\begin{array}{l}0.96 \\
0.52 \\
1.09\end{array}$ & $\begin{array}{r}19 \cdot 35 \\
6 \cdot 68 \\
18 \cdot 03\end{array}$ & $\begin{array}{l}3 \cdot 52 \\
1 \cdot 28 \\
2 \cdot 96\end{array}$ & $\begin{array}{r}172 \cdot 14 \\
68 \cdot 15 \\
169 \cdot 82\end{array}$ & $\begin{array}{r}12 \cdot 14 \\
5 \cdot 93 \\
10 \cdot 72\end{array}$ \\
\hline & $\mathbf{B}$ & $\begin{array}{l}\text { Salary } \\
\text { Piecework } \\
\text { Salary }\end{array}$ & $\begin{array}{l}2 \cdot 01 \\
4 \cdot 95 \\
1 \cdot 86\end{array}$ & $\begin{array}{l}0.48 \\
1 \cdot 03 \\
0.52\end{array}$ & $\begin{array}{r}5 \cdot 28 \\
18 \cdot 96 \\
4 \cdot 38\end{array}$ & $\begin{array}{l}1 \cdot 13 \\
3 \cdot 01 \\
1 \cdot 32\end{array}$ & $\begin{array}{r}72 \cdot 18 \\
191 \cdot 13 \\
69 \cdot 72\end{array}$ & $\begin{array}{r}6 \cdot 28 \\
16 \cdot 15 \\
7 \cdot 24\end{array}$ \\
\hline
\end{tabular}


TABLE II

MEAN AND STANDARD ERROR (SEM) FOR URINARY EXCRETION OF ADRENALINE, NORADRENALINE, AND 11-HYDROXYCORTICOSTEROIDS FOR EACH PERIOD DURING ASSEMBLY LINE AND ORDINARY WORK II

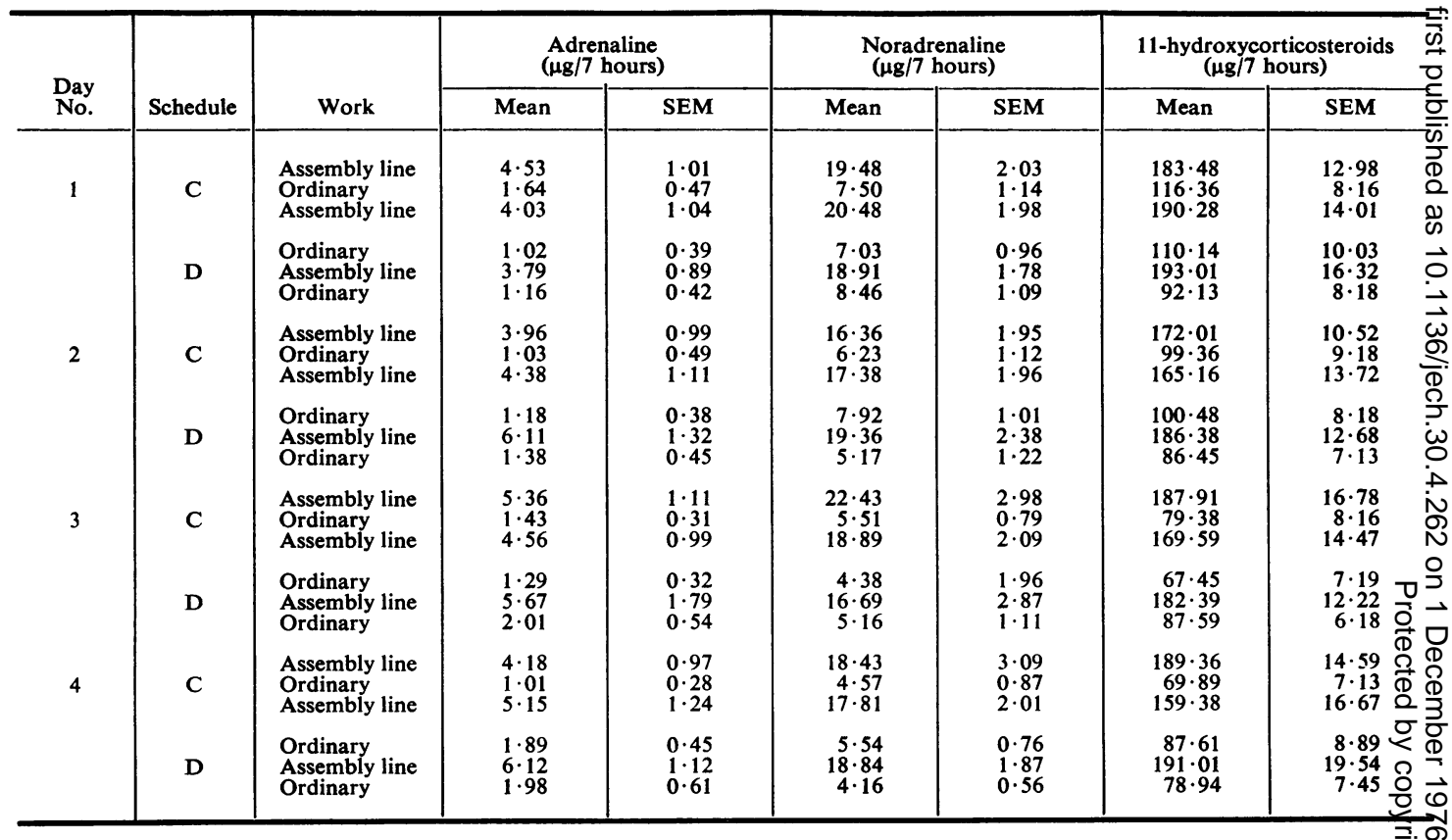

known about the physiological and psychological responses they determine. A few investigations have been aimed at quantifying a response in terms of significant changes in physiological function as reflected by modification of certain blood and urine constituents during everyday working life.

Levi (1972a) conducted a controlled experiment on white-collar workers to compare sympathoadrenomedullary activity during piecework and under salaried conditions. He found there was a significant increase in urinary adrenaline and noradrenaline excretion for piecework that reflected a corresponding augmentation in distress as judged by increment in rush, fatigue, and physical discomfort ratings.

We studied adrenosympathetic and adrenocortical activity in two groups of blue-collar workers under two types of working conditions: payment by results and assembly line. In piecework and on the assembly line, urinary adrenaline, noradrenaline, and 11-hydroxycorticosteroid excretion levels rose significantly compared with the values observed during daily salaried and 'ordinary' work. It might be argued that increases in catecholamines and 11-hydroxycorticosteroid excretion reflect corresponding increases in muscular work during the four days of piecework and assembly line work. But although muscular work affects adrenaline and noradrenaline releasse this is only true of rather high intensity of the activity (Levi, 1972b); in addition exertion of the confectioner and the metallurgists was identical during each phase of the observation. Therefore it seems justified to assume that hormonal increase reflects a correspond $\overrightarrow{\vec{E}}$ ing augmentation in stress and distress. These result $\bar{乛}$ support the empiric view that piecework an assembly line systems produce stresses in apparentl. normal subjects.

The difference between adrenosympathetic and adrenocortical reaction to two working types and the response to 'normal' working conditions, persisted. almost unchanged, throughout the four days o $\$$ observation. We do not know whether this difference diminishes after prolonged exposure to working stress, as normal environmental stimuli could decrease in psychoendocrine reaction intensite. (Levi, 1972b). However, in our opinion, this was not the case in the present study, because all those wh8 took part had been exposed to the same conditions for at least one year. On the other hand the crossoved design involving division of each group into two sub groups with alternate schedules of work, avoided the possible conditioning of the metabolic response duf to awareness of the aim of the study. The resulfs indicate that there is a persistent physiological 
reaction to long-term exposure of psychosocial stimuli, this being in the same direction and of the same order of magnitude as that described during short-term exposure in other types of everyday stress and distress.

One may speculate that lasting exposure to psychological stress at work could in the long run badly influence cardiac 'performance' through direct and metabolic effects of catecholamines and 11hydroxycorticosteroids, especially in men with preclinical signs of atherosclerosis and coronary heart disease. The hypothesis that some factors inherent in modern working conditions precipitate an additional coronary risk condition, deserves further study.

Requests for reprints: Mario Timio MD, Patologia Medica-Policlinico Monteluce, University of Perugia, 06100 Perugia, Italy.

\section{REFERENCES}

ANITESCO, C. (1972). Study of the influence of noise and vibrations on the behaviour of catecholamines in industrial vibratory acoustic stress. Arch. Mal. prof., 33, 365.
Crout, R. J. (1961). Catecholamines in urine. In Standard Methods of Clinical Chemistry, edited by D. Seligson, p. 62. Academic Press, London.

LEVI, L. (1972a). Psychological and physiological reaction to and psychomotor performance during prolonged and complex stressor exposure. Acta med. scand., Supplement 528, 191, 119.

(1972b). Methodological considerations in psychoendocrine research. Acta med. scand., Supplement $528,191,28$.

MatTingly, D. (1962). A simple fluorimetric method for the estimation of free 11-hydroxycorticosteroids in human plasma. J. clin. Path., 15, 374.

, Dennis, P. M., Pearson, J., and Cope, C. L. (1964). Rapid screening test for adrenal cortex function. Lancet, 2, 1046.

Raven, P. B., Conners, T. J., and Evonuk, E. (1970). Effects of exercise on plasma lactic deydrogenase isozymes and catecholamines. J. appl. Physiol., 29, 374.

Valori, C., Brunori, C. A., Renzini, V., Porcellati, C., and COREA, L. (1970). Improved procedure for formation of epinephrine and norepinephrine fluorophors by the trihydroxyindole reaction. Analyt. Biochem., 33, 158. 